\title{
Development of a Geographic Information Systems Baseline Spatial Geodatabase Template for Evaluating Potential and Predicted Environmental Impacts for Sustainable Environmental Impact Assessment of Mining in Sierra Leone
}

\author{
Samuel Mohamed Kamara \\ Department of Geographic Information Systems, Environment Protection Agency, Freetown, Sierra Leone \\ Email: samuel.kamara@epa.gov.sl,samrata001@yahoo.co.uk
}

How to cite this paper: Kamara, S. M. (2020). Development of a Geographic Information Systems Baseline Spatial Geodatabase Template for Evaluating Potential and Predicted Environmental Impacts for Sustainable Environmental Impact Assessment of Mining in Sierra Leone. Journal of Geoscience and Environment Protection, 8, 262-284.

https://doi.org/10.4236/gep.2020.810018

Received: June 26, 2020

Accepted: October 27, 2020

Published: October 30, 2020

Copyright $\odot 2020$ by author(s) and Scientific Research Publishing Inc. This work is licensed under the Creative Commons Attribution International License (CC BY 4.0).

http://creativecommons.org/licenses/by/4.0/

\begin{abstract}
Baseline Environmental Impact Assessment (EIA) of mining projects in Sierra Leone creates a challenging environment for data collection and impact prediction. Application of geographic information systems provides suitable spatial analysis data collection methods to reduce the challenges created by mining environments. This research develops a baseline spatial geodatabase template for evaluating potential and predicted environmental impacts assessment of mining projects in Sierra Leone. It is observed that spatial analysis of impacts of mining projects on the environmental attributes, especially air, noise, water, land, and socio-economy in mining areas is largely unexplored in Sierra Leone. The literature review revealed that no complete GIS spatial data geodatabase collection template appears to have been developed to date to provide an integrated sustainable spatial analysis and modelling tool for EIA and environmental management of mining in Sierra Leone. Therefore developing a Geographic Information Systems baseline geodatabase template for the evaluation of potential and predicted environmental impact for sustainable environmental impact assessment of mining in Sierra Leone will: 1) provide support to the data acquisition process of environmental impact assessment, 2) offer a concept for developing analysis methods for environmental management of mining, 3) minimize the undesired environmental impacts of mining, and 4) give an optimal proposal for data collection and analysis of mining industry in attaining sustainable development in Sierra Leone. Due to the limited available data, a conceptual GIS database tem-
\end{abstract}


plate has been developed rather than a database case study of a mining site. No site investigation and data collection were undertaken. The geospatial database template was designed using ArcCatalog, ArcGIS 10.7.1. software, through the following steps: exploration of the general data requirement of environmental impact assessment studies of mining, the definition of the general baseline datasets requirement of environmental impact assessment in mining, structuring of the environmental impact assessment baseline spatial geodatabase, creating the geographic geodatabase dictionary, selecting, matching geographic data with geodatabase structure, designing the feature class and attributes, creating the baseline GIS geodatabase template. The GIS spatial geodatabase template has several advantages for environmental impact assessment of mining including avoiding data redundancy, integrating data into a single database, creating uniformity in data collection, easy to find and track data, integrated spatial and non-spatial data, and reducing the volume of data.

\section{Keywords}

GIS, Environmental Impact Assessment, Spatial Geodatabase, Sustainable Environment

\section{Introduction}

Environmental Impact Assessment (EIA) was formally adopted in Sierra Leone in 2010 (EPA-SL Act, 2010) as a measure to protect the environment and to reduce environmental degradation associated with major developmental projects. Although Environmental Impact Assessments (EIAs) are dependent on geo-spatial information to make an assessment, there are no rules set on how to conduct an environmental assessment on mining activities in Sierra Leone. Since GIS is a vital tool and efficient in data collection, storage, analysis, and collation, it has become an appropriate mechanism for creating an environmental information system spatial geodatabase. This storage ability makes environmental spatial and non-spatial data easier to upgrade, update, process, and retrieve as needed. GIS is applicable in all stages of the EIA process: from the acquisition, storage, processing, manipulating and display of thematic information relative to the vulnerability of the affected natural resources. Geographic Information Systems (GIS) can improve the gathering, storage manipulation, transformation and processing of data and information. GIS contribution to environmental impact assessment studies is very important and very useful for managing environmental impact assessment and data consistently from field measurement (Kamara, 2019). Generally, an impact assessment study is an information collection and analysis process; thus, up-to-date, available, and relevant data are needed to attain useful results (Bulla et al., 2004). The section of the EIA report of mining that often describes the detailed environmental baseline conditions of a particular mining site demonstrates whether the EIA Consultant truly under- 
stands the environmental, social, health, and economic impact that the proposed mining project may create. For instance, if the EIA does not include details about the existing land cover/land use, vegetation, surface and groundwater quality, air quality, and the abundance and distribution of threatened and endangered species, then it simply is not possible for the EIA Consultant to formulate accurate information about how the project would impact land cover/land use, vegetation, surface and groundwater quality, air quality, and the abundance and distribution of threatened and endangered species. However, application of GIS in mining EIA in Sierra Leone is constrained by the availability of an appropriate digital electronic baseline geodatabase on environmental parameters and datasets, such as base maps on Land use/land cover, soil, geology, topography, population density, socio-economic levels, road accessibility, air quality, water quality, noise level, biological content, historical value, archaeological, climate change to name a few. Although very significant work has been done in environmental impact assessment and sophisticated Geological Information Systems has been developed to determine the location of mineral deposit and ore bodies, no complete GIS spatial geodatabase template for spatial data collection appears to have been developed to date to provide an integrated sustainable spatial analysis and modelling tool for EIA and environmental management of mining in Sierra Leone. This is due to 1) the absence of comprehensive understanding of interrelated environment impacts caused by the mining of different minerals, 2) the environmental uniqueness of each mine, which make it difficult to develop general tools of EIA analysis and models, 3) the availability of adequate spatial data, information and appropriate GIS technics, 4) because of the dynamic characteristics and multivariate nature of the environment, it has often been difficult to collate, analyze and interpret its datasets, 5) lack of appropriate temporal and spatial resolution of remotely sensed imageries and accurate geospatial data can be a major limitation on spatial modeling, 6) finally, the availability of GIS professionals and affordability of GIS software and related hardware is a major constraint on EIA budgeting, especially for developing countries like Sierra Leone. Most EIA studies of mining projects have focused only on one or a limited set of impacts of the project on the physical, ecological, or social environment. Thereby, such studies have not provided a holistic picture of the entire environmental impact scenario. The research aims to design a Geographic Information Systems baseline geodatabase template for the evaluation of potential and predicted environmental impact for sustainable environmental impact assessment of mining in Sierra Leone. The expected output is an application in the ArcGIS software environment where the no GIS expert and environmentalist can easily use the templates to collect and analyze the data and get a comprehensive analysis and results. This study will add a more meaningful contribution to studies already done by other researchers in the integration of GIS and GIS software to solve the problems in the EIAs of mining. Each step will be explained in detail in the subsequent sections. Therefore, it is expected that the environmental databases from mining companies have uniformity in all data 
collection procedures, field measurement procedures, results classification and data management, analysis method, and reporting data systems to the environmental impact assessment. The GIS spatial geodatabase template has several advantages for environmental impact assessment of mining including avoiding data redundancy, integrating, data into a single database, creating uniformity in data collection, easy to find and track data, integrated spatial and non-spatial data, and reducing the volume of data storage. This study will add a more meaningful contribution to studies already done by other researchers in the integration of GIS and GIS software to solve the environmental problems of mining. According to the trial done on the baseline GIS spatial geodatabase template, it has shown some encouraging results for evaluating potential and predicted environmental impacts assessment of mining projects in Sierra Leone. However, using the baseline spatial geodatabase template has many advantages; however, there are also several challenges to implement it as stated above.

\section{Materials and Methods}

The process of designing the geospatial database was accomplished by using a relational personal geodatabase concept. The geodatabase consists of ten feature datasets; the geospatial database template was designed using ArcCatalog, ArcGIS 10.7.1. software, through the following steps:

1) exploration of the general data requirement of environmental impact assessment studies of mining,

2) defining the general baseline datasets requirement of environmental impact assessment in mining,

3) structuring of the environmental impact assessment baseline spatial geodatabase,

4) creating the geographic geodatabase dictionary,

5) selecting, matching geographic data with geodatabase structure,

6) designing the feature class and attributes,

7) creating the baseline GIS spatial geodatabase template.

Each step will be explained in detail in the subsequent sections.

\subsection{Exploration of the General Data Requirement}

The first step in this research was to study the specifications relative to data contained in national laws and regulations about an environmental impact analysis of mining in Sierra Leone. The relevant literature and ESHIA reports of mining companies in Sierra Leone were explored; moreover, in the course of my investigations, I examined 54 environmental impact assessments, of which 30 were completed environmental impact studies for small scale mining companies' reports documentations and 14 were completed environmental impact studies for large scale mining companies. Most of the environmental impact assessments for investigation were selected through the impact assessment database of the Environmental Cadastral and Administrative system (ECAS) electronic system which 
are studies conducted by different environmental consulting firms in Sierra Leone. In the course of my investigation, I determined the general primary environmental data that the laws of Sierra Leone prescribe or recommends, or that were used by the authors of the examined environmental impact assessments for the various mining companies. On this basis, a data list was compiled containing only those data fields that occurred with at least $85 \%$ frequency in the examined impact assessment studies as a result of statistical evaluation.

\subsection{Definition of the General Datasets Requirement}

In examining the phases and work stages of environmental impact assessment, it was established that the data collection and surveying phase is primarily the basic state in which databases or information systems can serve as potential data sources. Consequently, in this research, the analysis of data needed for the examination of the basic state of the environment was emphasized; hence, they are taken into consideration for impact assessment and appraisal. The following gives a more detailed discussion of the specific kinds of environmental baseline datasets that an EIA for a proposed mining project needs to contain. Those environmental data were incorporated into my master data list, which occurred in at least $(85 \%)$ of the studies that were investigated. Table 1 shows the primary data grouped as elements of the environment.

Table 1. General baseline datasets of environmental impact assessments of mining.

\begin{tabular}{|c|c|}
\hline Soil & $\begin{array}{l}\text { topography, geomorphology, geological structure and bedrock, parent } \\
\text { material, the direction of slope, genetic and physical soil type, water balance, } \\
\text { location and sensitivity of the soil layers, soil texture, pH, soil water } \\
\text { management categories, depth of the column, soil compaction depth of the } \\
\text { groundwater, protected geological values }\end{array}$ \\
\hline Air & $\begin{array}{l}\text { average hours of sunshine, prevailing wind direction, wind speed, } \\
\text { precipitation conditions, the spatial and temporal distribution of rainfall, } \\
\text { average temperature data, air quality, background contamination, } \\
\text { protected and sensitivity categories }\end{array}$ \\
\hline Water & $\begin{array}{l}\text { size and location of surface and groundwater, water flow conditions, standard } \\
\text { flow, protected hydrological values, water facilities, water quality (pH, Total } \\
\text { suspended residue, Fe Total, and } \mathrm{Mn} \text { Total) }\end{array}$ \\
\hline $\begin{array}{l}\text { Wildlife, Biological } \\
\text { Flora \& fauna }\end{array}$ & $\begin{array}{l}\text { types of habitat, habitat patches, species composition, rare plant communities, } \\
\text { protected plants, animal species and population of the examined area, } \\
\text { protected animals }\end{array}$ \\
\hline Socio-Economic & $\begin{array}{l}\text { size and distance of built environment, built-up, cultural values, historical } \\
\text { monuments, function of the examined area }\end{array}$ \\
\hline Base Map & $\begin{array}{l}\text { Administrative boundary, Concession area boundary, District boundary, } \\
\text { Chiefdom boundary, Section boundary, Scanned parcel Maps, Digital Orth } \\
\text { photos, imagery }\end{array}$ \\
\hline Population & the size of the affected population, population by sex and age \\
\hline Land cover/land use & $\begin{array}{l}\text { landscape, land use, nature-function areas, protected areas, } \\
\text { landscape values }\end{array}$ \\
\hline
\end{tabular}




\subsection{Structuring the Geospatial Database}

The structure of the spatial geodatabase includes two types of data, i.e. Spatial and non-spatial (attributes data). The structure of the spatial geodatabase contains ten features datasets namely: the basemap dataset, the air quality dataset, water quality dataset, the population dataset, the flora and fauna datasets (biological dataset), land cover/land use datasets, socio-economic datasets, waste management dataset, climate change dataset and soil quality dataset as shown in Figure 1.

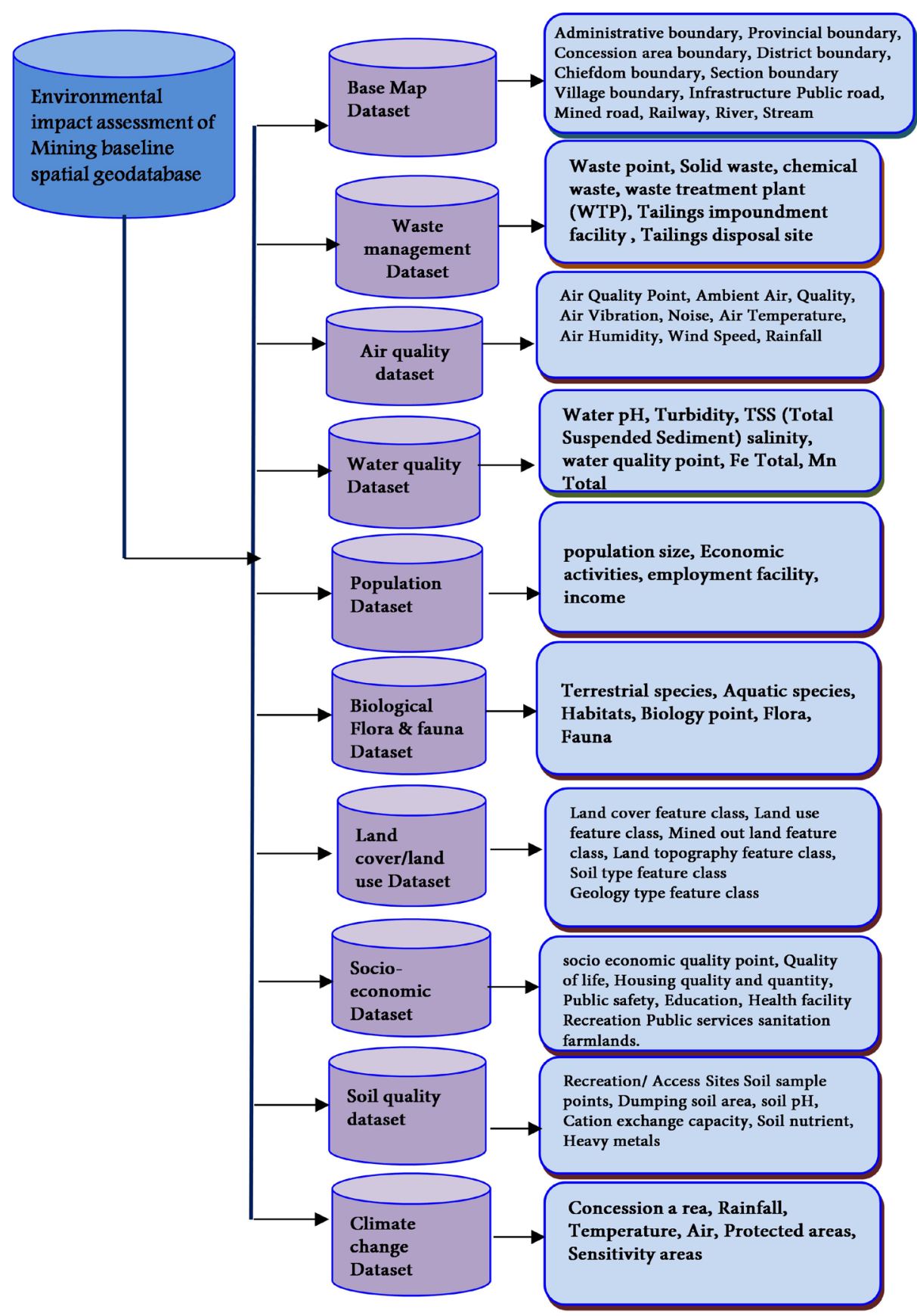

Figure 1. Structure of the environmental impact assessment baseline spatial geodatabase. 


\subsection{Creating the Geographic Geodatabase Dictionary}

The data dictionary is the result of the analysis phase of existing needs in terms of geospatial data. This data is available either in analog form (maps) or digital (computer support). A data dictionary is a collection of metadata and necessary reference data for designing a geographic database and is a catalog or table containing information about the datasets stored in a database It describes data definition, data type, coordinate system, feature class field properties, relationship diagram, and reference table. It's contained the full names of attributes, meanings of codes, the scale of the source data, accuracy of locations, and map projections used. Creating a data dictionary allows other users to view formation about the data. The data dictionary is useful for environmental practitioners, engineers, surveyors, GIS experts, and analysts for data processing and analysis, GIS users and decision-makers, environmental technicians involving in EIA studies of mining. This is the main referential of the database template. It is often represented by a table containing the name, code, data type, and comments, etc. as shown in Figure 2.

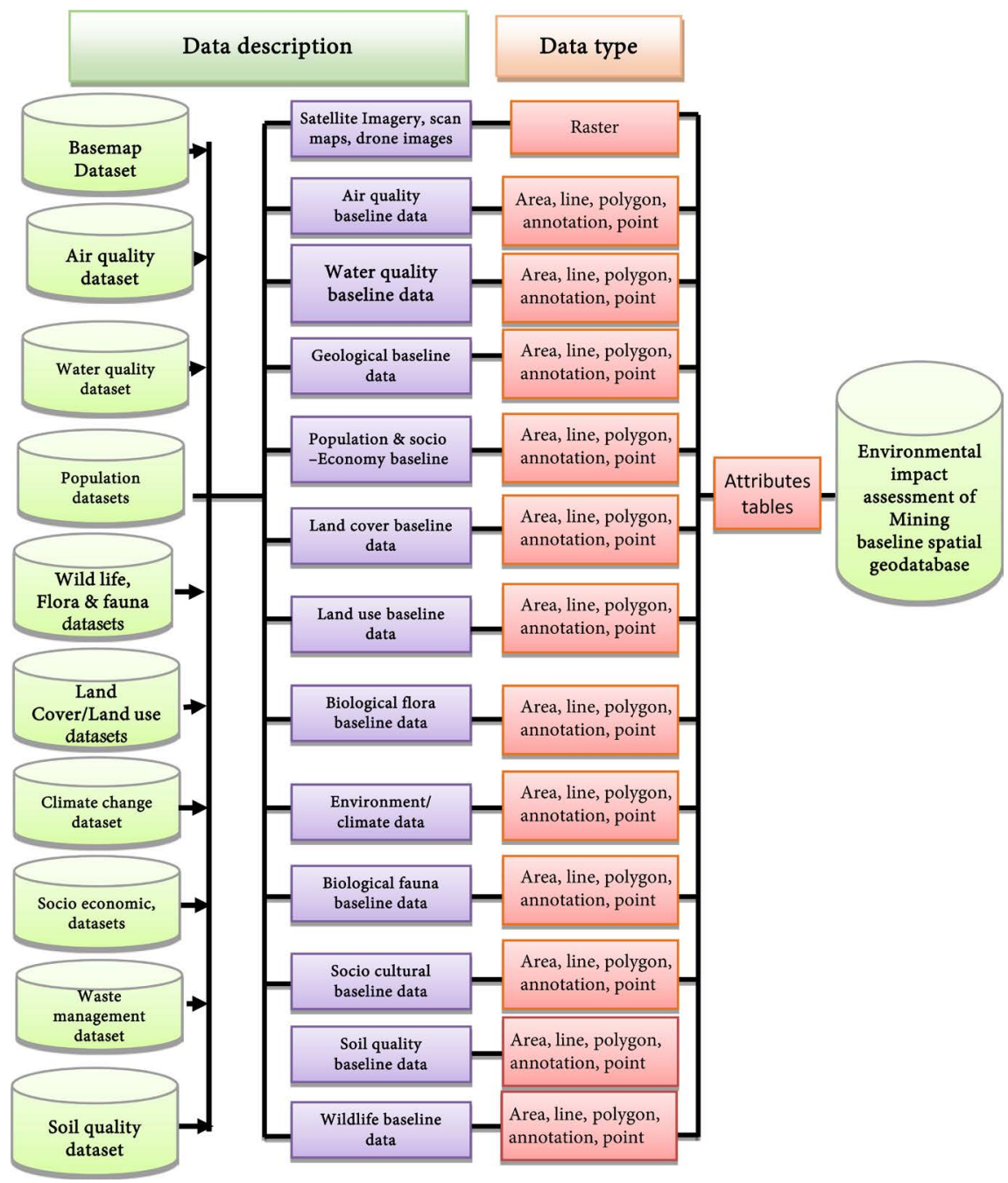

Figure 2. Geographic data dictionary of the geodatabase. 


\subsection{Selecting, Matching Geographic Data with Geodatabase Structure}

GIS database design is about identifying the thematic layers to be used and specifying the contents and representations of each thematic layer. This involves defining how the geographic features are to be represented (for example, as points, lines, polygons, raster's, or tabular attributes); how the data is organized into feature classes, attributes, and relationships; and the spatial and database integrity rules for implementing rich GIS behavior using topologies, networks, raster catalogs, and so forth. Designing of feature classes and attributes is the most important step in the building of the template databases because this step determines what the database looks like. This step includes determination of the following feature class name, coordinate system, data type, field name and field properties, code for each environment parameters, and creating reference tables. The baseline spatial geodatabase contains a series of GIS data layers. The list above, sorted by layer category, shows the vector data layers in the database that model real-world features as points, lines, or polygons in a UTM (WGS 1984) projected geographic coordinate system. All feature classes in the geodatabase have the following common attributes as shown in Table 2.

The NAME attribute is used in ArcMap for labelling purposes, and most of the feature classes have a typical characteristic that is used for symbolizing features. The remaining attributes are primarily used for quality control and metadata purposes. The environmental impact assessment baseline spatial geodatabase model template consists of a set of core templates (sub-models) and extensions. These core templates and extensions can be linked using a common theme in the model, i.e. the concession area.

A concession area can be represented as a polygon, using a unique identifier for each concession area. Templates may interact with each other with a combination of spatial and non-spatial data with reference information to form the environmental impact assessment baseline spatial geodatabase layers, the geodatabase data model is dynamic; it will provide flexibility for end-users to manipulate the selection criteria and organizing them on a priority basis depending on the development strategies considered.

Table 2. Common Attributes of the geodatabase.

\begin{tabular}{|c|c|c|c|}
\hline Attribute & Data Type & Length & Description \\
\hline NAME & String & 200 & An attribute that is typically used for labeling the feature. \\
\hline SOURCEFEATUREID & String & 20 & $\begin{array}{l}\text { Unique ID of the feature. This attribute should be mapped to the source dataset's } \\
\text { unique feature ID. }\end{array}$ \\
\hline DATASOURCENAME & String & 100 & Data source name (geodatabase name, shapefile name, and so on). \\
\hline LASTUPDATE & Date & 8 & Date when the feature was last loaded or updated. \\
\hline ISVISIBLE & Small Integer & 2 & A flag used for turning features on and off in ArcMap through definition queries \\
\hline LASTEDITOR & String & 100 & Name of the person who migrated or edited the data. \\
\hline EDITCOMMENTS & String & 250 & Description of the edit performed on the feature. \\
\hline
\end{tabular}




\section{Results}

\subsection{Creating the Baseline GIS Geodatabase Template}

The GIS baseline geodatabase was created in the ArcCatalog of the ArcGIS Desktop 10.7.1. Software. This is a collection of feature datasets and a feature dataset is a group of feature classes. This step includes 1) creating personal geodatabase, 2) creating feature datasets, 3) creating feature class, and 4) determine the feature class properties. Figure 3 shows the personal Environmental GIS baseline Spatial Geodatabase in the ArcCatalog, ArcGIS Software. This geodatabase contains ten (10) feature datasets.

A feature is a collection of features representing the same geographic elements such as boreholes, drill holes, parcels, or soil types, etc. All the features in a future class have the same spatial representation (for example point, line, or polygon) and share a common set of descriptive attributes. Feature datasets are organized collections of related feature classes (Maryati et al., 2012). The feature class properties (Figure 4) provide information regarding field properties, domain indexes, subtypes, relationship, representation, coordinate system, tolerance, and resolution. All information about the spatial data is stored in the field's attribute. The field properties include the field name, data type, alias, allow null values, default value, and length as shown in Figure 4. The baseline environmental GIS spatial database template for a proposed mining project contained ten (10) datasets. The creation of each of these datasets is explained in the following sections.

\subsection{Creating the Baseline Base Map Dataset}

The base map datasets are the datasets that contain the feature classes that are to be used as a base map for the creation of the thematic maps for the baseline environmental impact assessment of mining projects. This dataset includes Administrative boundary, Provincial boundary, Concession area boundary, District boundary, Chiefdom boundary, Section boundary, Village boundary Infrastructure, Public road, mined road, Railway, and River as shown in (Figure 5). From Figure 5, the GIS Base map personal geodatabase was created in the ArcCatalog of the ArcGIS Desktop 10.7.1. Software. Table 3 shows the description of the baseline base map layers' attributes.

\subsection{Creating the Baseline Land Cover/Land Use Dataset}

The land cover/land use datasets are the datasets that contain the feature classes to be used as a base map for the creation of the land cover/land use thematic maps for the baseline environmental impact assessment of mining projects. It contains mainly the feature classes related to the mining operations in the project concession area which includes; land cover feature class, land use feature class, mined-out land feature class, land topography feature class, soil type feature class, geology type feature class as shown in Figure 6. Table 4 shows the description of the baseline land cover/land use layers' attributes. 


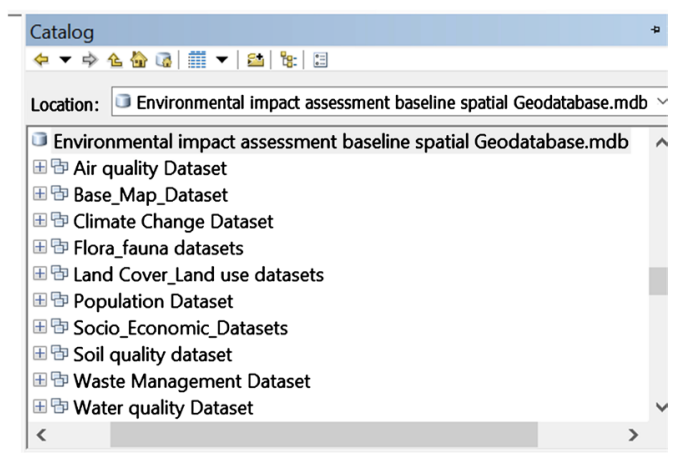

Figure 3. Environmental GIS baseline spatial geodatabase.

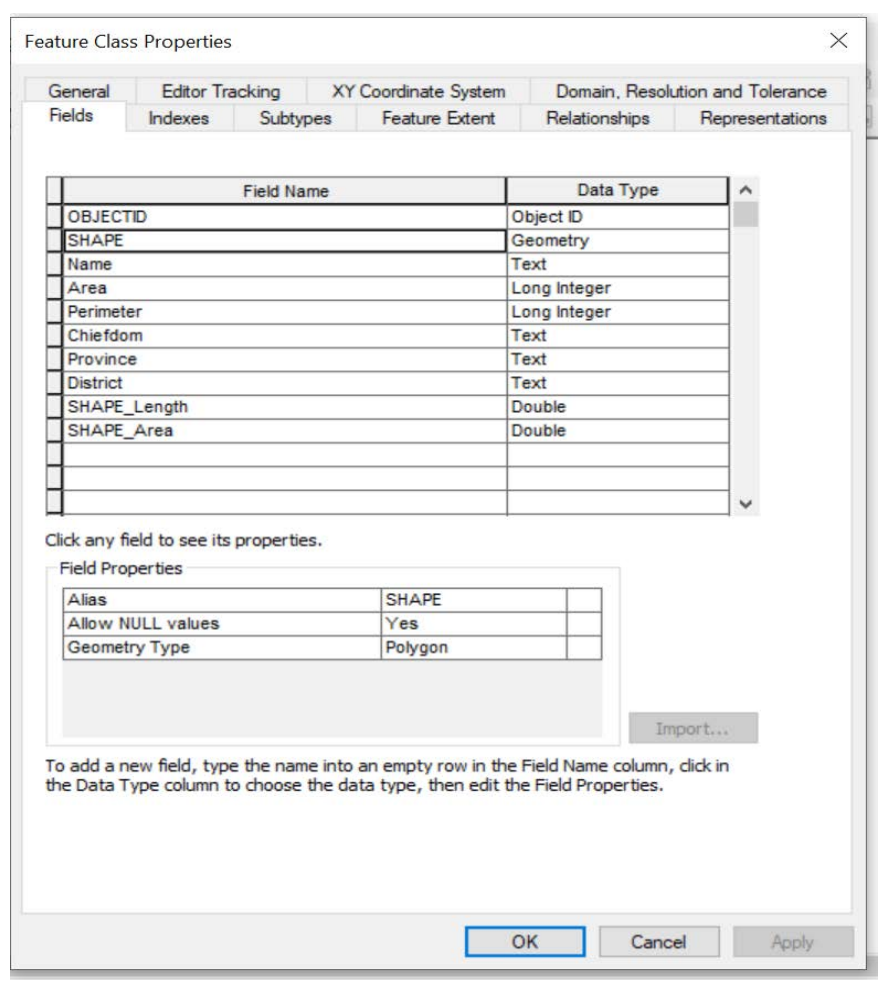

Figure 4. Feature class properties.

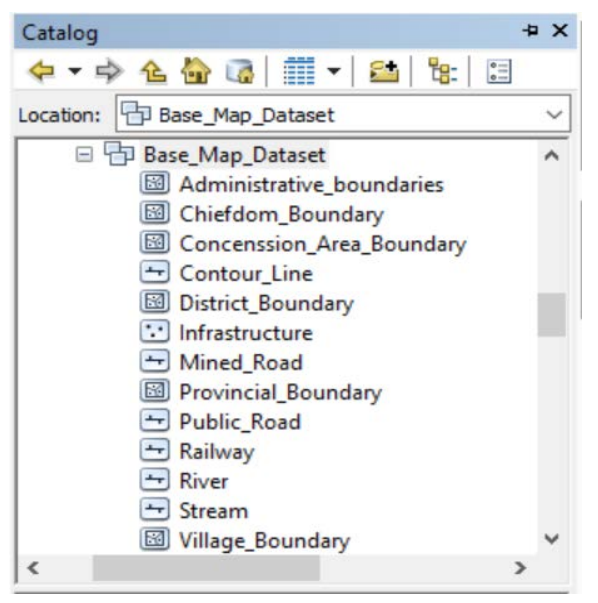

Figure 5. Feature classes of baseline base map. 


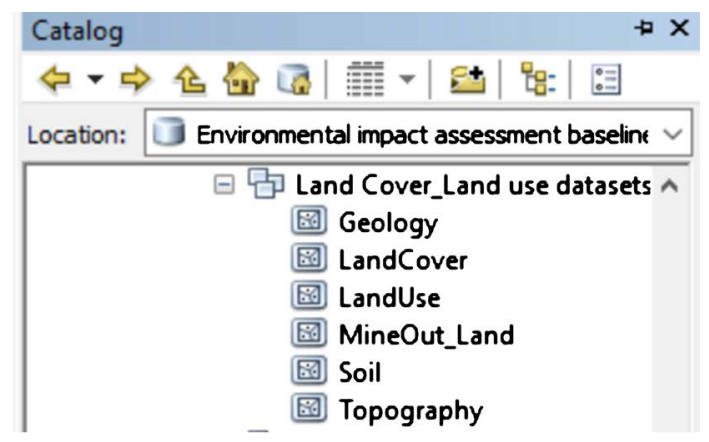

Figure 6. Feature classes of baseline land cover/land use dataset.

Table 3. Description of the baseline land cover/land use dataset.

\begin{tabular}{|c|c|c|c|c|}
\hline No & LAYER & $\begin{array}{l}\text { Requirement } \\
\text { Level }\end{array}$ & $\begin{array}{l}\text { Geometry } \\
\text { Type }\end{array}$ & Required Attributes \\
\hline 1 & Contour & Required & Polyline & $\begin{array}{l}\text { Elevation, Slope, Contour ID, Shape, Contour } \\
\text { Type, Height, Collection Date, Remarks, } \\
\text { SHAPE_Length }\end{array}$ \\
\hline 2 & $\begin{array}{l}\text { Administrative } \\
\text { Boundary }\end{array}$ & Required & Polygon & $\begin{array}{l}\text { Name, Adm ID, Shape, SHAPE_Length, } \\
\text { SHAPE_area, Collection Date, Remarks }\end{array}$ \\
\hline 3 & Stream & Required & Polyline & $\begin{array}{l}\text { Stream Name, Stream ID, Shape, } \\
\text { SHAPE_Length, Stream Type, Collection Date, } \\
\text { Remarks }\end{array}$ \\
\hline 4 & $\begin{array}{l}\text { Provincial } \\
\text { boundary }\end{array}$ & Required & Polygon & $\begin{array}{l}\text { Name, Type, Province Code, SHAPE_Length, } \\
\text { SHAPE_area }\end{array}$ \\
\hline 5 & $\begin{array}{l}\text { Concession } \\
\text { area } \\
\text { boundary }\end{array}$ & Required & Polygon & $\begin{array}{l}\text { Name, Shape SHAPE_Length, SHAPE_area, } \\
\text { Con ID, Application Month, Application Year, } \\
\text { Mapping date, Mapper name, Remarks }\end{array}$ \\
\hline 6 & $\begin{array}{l}\text { District } \\
\text { boundary }\end{array}$ & Required & Polygon & $\begin{array}{l}\text { Name, Type, District Code, SHAPE_Length, } \\
\text { SHAPE_area }\end{array}$ \\
\hline 7 & $\begin{array}{l}\text { Chiefdom } \\
\text { boundary }\end{array}$ & Required & Polygon & $\begin{array}{l}\text { Name, Chiefdom Code, SHAPE_Length, } \\
\text { SHAPE_area }\end{array}$ \\
\hline 8 & Railway & Required & Polyline & $\begin{array}{l}\text { Rail ID, Shape, SHAPE_Length, Surface Type, } \\
\text { Rail Condition, Rail Name, Rail Type, Remarks }\end{array}$ \\
\hline 9 & $\begin{array}{l}\text { Village } \\
\text { boundary }\end{array}$ & Required & Polygon & $\begin{array}{l}\text { Name, Village ID, Shape, SHAPE_Length, } \\
\text { SHAPE_area, Mapping Date, Remarks }\end{array}$ \\
\hline 10 & Infrastructure & Required & Polygon & $\begin{array}{l}\text { Name, Inf ID, Shape, SHAPE_Length, } \\
\text { SHAPE_area, Collection Date, Remarks }\end{array}$ \\
\hline 11 & Public Road & Required & Polyline & $\begin{array}{l}\text { Road ID, Shape, SHAPE_Length, Surface Type, } \\
\text { Road Condition, Road Name, Road Type, } \\
\text { Remarks }\end{array}$ \\
\hline 12 & Mined road & Required & Polyline & $\begin{array}{l}\text { Road ID, Shape, SHAPE_Length, Surface Type, } \\
\text { Road Condition, Road Name, Road Type, } \\
\text { Remarks }\end{array}$ \\
\hline 13 & River & Required & Polyline & $\begin{array}{l}\text { River ID, Shape, SHAPE_Length, River Type, } \\
\text { River Name, Collection Date, Remarks }\end{array}$ \\
\hline
\end{tabular}


Table 4. Description of the baseline land cover/land use dataset.

\begin{tabular}{|c|c|c|c|c|}
\hline No & LAYER & $\begin{array}{l}\text { Requirement } \\
\text { Level }\end{array}$ & $\begin{array}{l}\text { Geometry } \\
\text { Type }\end{array}$ & Required Attributes \\
\hline 1 & Land cover & Required & Polygon & $\begin{array}{l}\text { Land cover ID, Land Cover type, Shape, } \\
\text { SHAPE_Length, SHAPE_area } \\
\text { Mapping Date, Remarks }\end{array}$ \\
\hline 2 & Land Use & Required & Polygon & $\begin{array}{l}\text { Land Use ID, Land Use type, Shape, } \\
\text { SHAPE_Length, SHAPE_area } \\
\text { Mapping Date, Remarks }\end{array}$ \\
\hline 3 & $\begin{array}{l}\text { Mined } \\
\text { outland }\end{array}$ & Required & Polygon & $\begin{array}{l}\text { Land Use ID, Land Use type, Shape, } \\
\text { SHAPE_Length, SHAPE_area } \\
\text { Mapping Date, Remarks }\end{array}$ \\
\hline 4 & $\begin{array}{l}\text { Land } \\
\text { Topography }\end{array}$ & Required & Polygon & $\begin{array}{l}\text { Land Use ID, Topography type, Shape, } \\
\text { SHAPE_Length, SHAPE_area } \\
\text { Mapping Date, Remarks }\end{array}$ \\
\hline 5 & Soil & Required & Polygon & $\begin{array}{l}\text { Land Use ID, Soil type, Shape, } \\
\text { SHAPE_Length, SHAPE_area } \\
\text { Mapping Date, Remarks }\end{array}$ \\
\hline 6 & Geology & Required & Polygon & $\begin{array}{l}\text { Land Use ID, Geology type, Shape, } \\
\text { SHAPE_Length, SHAPE_area } \\
\text { Mapping Date, Remarks }\end{array}$ \\
\hline
\end{tabular}

\subsection{Creating the Baseline Air Quality Dataset}

Baseline Air quality datasets for a mining project concession area are critical to evaluating the potential distribution of air pollutants and their effects in the area of influence. Air pollutants can travel long distances, so baseline air quality information should be considered about meteorological conditions, wind patterns, geological formations, and anything else that might influence the distribution of air pollutants. Baseline air quality datasets should include the following: location of air monitoring and/or sampling stations and measurements of these common parameters; Particulate matter (PM10 and PM2.5), Carbon monoxide (CO), Nitrogen oxides (NOx), Lead $(\mathrm{Pb})$, cadmium $(\mathrm{Cd})$, arsenic (As), mercury $(\mathrm{Hg})$, Total Suspended Solids (TSS), and Sulfur dioxide $\left(\mathrm{SO}_{2}\right)$. This dataset includes noise, air temperature, air humidity, wind speed rainfall, air quality point, ambient air quality, and air vibration, Figure 7 illustrates the design of the geodatabase in the ArcGIS/ArcCatalog software. As can be seen in Figure 7, the Air quality datasets contain eight feature classes. Attributes of these future classes are further illustrated in Table 5.

\subsection{Creating the Baseline Wildlife, Flora and Fauna Datasets}

The wildlife datasets comprise all living things that are undomesticated. This includes plants, animals (vertebrates, birds, fish), and other organisms (invertebrates). The baseline wildlife, flora, and fauna datasets must include a list of wildlife species within the project area and interactions between species. This should include all endemic flora and fauna in the project concession area that have a special conservation status-for example, listed by the International Union for Conservation of Nature (IUCN) or by national legislation as a threatened 
or endangered species, a description of the region and species distribution. The dataset contains mainly feature classes related to wildlife, flora, fauna, and biodiversity. This dataset contains six feature classes includes terrestrial species, aquatic species, habitats critical to ecological processes, biology point. Figure 8 illustrates the design of the geodatabase in the ArcGIS/ArcCatalog software. Each feature class contains information regarding mapping point names and UTM XY position coordinates. Attributes of these future classes are further illustrated in Table 6.

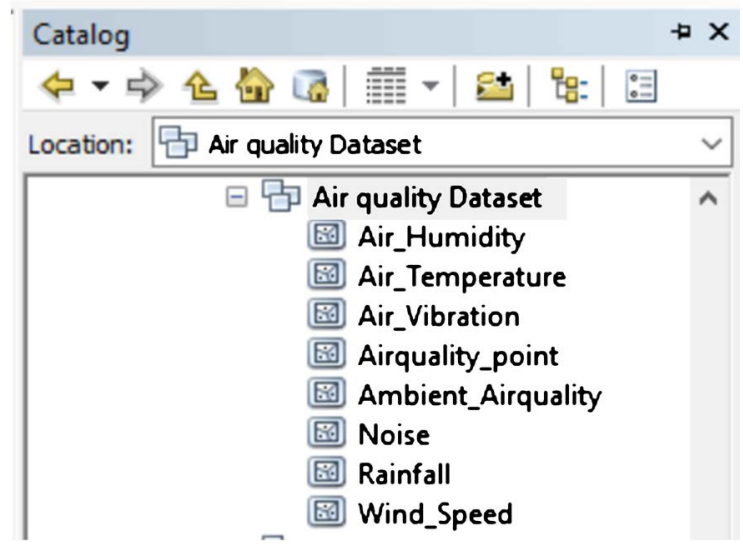

Figure 7. Feature classes of baseline air quality dataset.

\begin{tabular}{|c|c|c|}
\hline Location: & 埴 Flora_fauna datasets & $\checkmark$ \\
\hline 日它 F & lora_fauna datasets & $\wedge$ \\
\hline & Aquatic_Species & \\
\hline & - Biological_Point & \\
\hline & Fauna & \\
\hline & Flora & \\
\hline & Habitats & \\
\hline & Terrestrial_Species & $\checkmark$ \\
\hline
\end{tabular}

Figure 8. Feature classes of the wildlife, flora and fauna dataset.

Table 5. Description of the baseline air quality dataset.

\begin{tabular}{|c|c|c|c|c|}
\hline No & LAYER & Requirement Level & Geometry Type & Required Attributes \\
\hline 1 & Air quality point & Required & Point & Air Quality ID Shape, Point Name, Mapping Date, Remarks \\
\hline 2 & Air Humidity & Required & Point & Air Quality ID, Shape, Point Name, Humidity, mapping Date, Remarks \\
\hline 3 & Ambient Air Quality & Required & Point & $\begin{array}{l}\text { Shape, Point Name, Sulphur Dioxide, Carbon Monoxide, Nitrogen Dioxide, } \\
\text { Oxidant, Hydro Carbon, } \mathrm{PM}<10, \mathrm{PM}<2.5 \text {, TSP, Plumbum, Dustfall, Tota } \\
\text { Florides, Fluor Index, Lead }(\mathrm{Pb}) \text {, Sulphate dioxide, Mapping Date, Remarks }\end{array}$ \\
\hline 4 & Air Vibration & Required & Point & Air Quality ID, Shape, Point Name, vibration, Mapping Date, Remarks \\
\hline 5 & Noise Point & Required & Point & Air Quality ID, Shape, Point Name, Noise, Mapping Date, Remarks \\
\hline 6 & Air Temperature & Required & Point & Air Quality ID, Shape, Point Name, Temperature, Mapping Date, Remarks \\
\hline 7 & Wind Speed & & Point & Air Quality ID, Shape, Point Name, Wind Speed, Mapping Date, Remarks \\
\hline 8 & Rain Fall & & Point & Air Quality ID, Shape, Point Name, Rain Fall, Mapping Date, Remarks \\
\hline
\end{tabular}


Table 6. Description of the baseline wildlife, flora and fauna dataset.

\begin{tabular}{|c|c|c|c|c|}
\hline No & LAYER & Requirement Level & Geometry Type & Required Attributes \\
\hline 1 & Terrestrial species & Required & Point/polygon & $\begin{array}{l}\text { Composition, Shape, Point Name, density, distribution } \\
\text { Status, X_Coordinate, Y_Coordinate, vegetative cover, Mapping Date, } \\
\text { Remarks }\end{array}$ \\
\hline 2 & Aquatic species & Required & Point/Polygon & $\begin{array}{l}\text { Composition, Shape, Point Name, density, distribution } \\
\text { Status, X_Coordinate, Y_Coordinate, Mapping Date, Remarks }\end{array}$ \\
\hline 3 & Habitats & Required & Point/Polygon & $\begin{array}{l}\text { Biology ID, Shape, Point Name X_Coordinate, Y_Coordinate, Results, } \\
\text { Mapping Date, remarks }\end{array}$ \\
\hline 4 & Biology point & Required & Point/Polygon & $\begin{array}{l}\text { Biology ID, Shape, Point Name } \\
\text { X_Coordinate, Y_Coordinate, Results Mapping Date, remarks }\end{array}$ \\
\hline 5 & Flora & Required & Point/Polygon & $\begin{array}{l}\text { Biology ID, Shape, Point Name } \\
\text { X_Coordinate, Y_Coordinate, Results Mapping Date, remarks }\end{array}$ \\
\hline 6 & Fauna & Required & Point/Polygon & $\begin{array}{l}\text { Biology ID, Shape, Point Name } \\
\text { X_Coordinate, Y_Coordinate, Results Mapping Date, remarks }\end{array}$ \\
\hline
\end{tabular}

\subsection{Creating the Baseline Surface and Groundwater Quality Dataset}

The baseline surface and groundwater quality datasets must include a list of Common water quality attributes such as Physical, chemical: $\mathrm{pH}$, turbidity, suspended solids, temperature, Dissolved Oxygen (DO), Biochemical Oxygen Demand (BOD), Chemical Oxygen Demand (COD), dissolved solids, salinity, conductivity and for groundwater should include; Groundwater flow directions, Locations/flows of springs and seeps, groundwater discharge locations in streams, groundwater uses, depth to groundwater under different seasonal conditions, geology and locations of aquifers, thicknesses, and their hydraulic conductivity ranges. Describing baseline surface water quality should provide detailed information on the location, distribution, quantity, and quality of all water resources that could be affected by a project and its alternatives. The data and analysis should have a reasonable level of detail, to help understand the conditions of the environmentally important geographic locations. When baseline water quality (surface water or groundwater) samples are collected, they should be analyzed for the full suite of parameters and contaminants of concern. This baseline surface and groundwater quality datasets contain seven feature classes including Water $\mathrm{pH}$, Turbidity, TSS (Total Suspended Sediment), salinity, water quality point, Fe Total, and Mn Total. Figure 9 illustrates the design of the geodatabase in the ArcGIS/ArcCatalog software. Attributes of these future classes are further illustrated in Table 7.

\subsection{Creating the Baseline Soil Quality Dataset}

The baseline soil quality datasets mainly contain feature classes related to soil based on conditions typically found in the mining concession area. Soil baseline studies are based on three major sources of information: desk study, fieldwork, and laboratory analysis. Baseline soil quality datasets should include measure- 
ments of these common parameters: soil composition, soil strength (resistance to crushing), mineral content, and $\mathrm{pH}$. Some measure of water content, organic content, soil texture, particle size, and bulk density. This dataset contains six feature classes includes soil sample points, dumping soil area, soil $\mathrm{pH}$, Cation exchange capacity, Soil nutrient (potassium, calcium, magnesium, nitrogen, phosphorus), and Heavy metals (lead, copper, zinc, cadmium, mercury, and chromium). Figure 10 illustrates the design of the geodatabase in the ArcGIS/ArcCatalog software. Attributes of these future classes are further illustrated in Table 8.

Table 7. Description of the baseline surface and groundwater dataset.

\begin{tabular}{|c|c|c|c|c|}
\hline No & LAYER & $\begin{array}{l}\text { Requirement } \\
\text { Level }\end{array}$ & $\begin{array}{l}\text { Geometry } \\
\text { Type }\end{array}$ & Required Attributes \\
\hline 1 & Water quality point & Required & Point & $\begin{array}{l}\text { Water Quality ID, Shape, } \\
\text { Point Name, X_Coordinates, Y_Coordinates, Mapping Date, Remarks }\end{array}$ \\
\hline 2 & $\begin{array}{l}\text { TSS (Total Suspended } \\
\text { Sediment) }\end{array}$ & Required & & $\begin{array}{l}\text { Water Quality ID, Shape, } \\
\text { Point Name, TSS, X_Coordinates, Y_Coordinates, Mapping Date, Remarks }\end{array}$ \\
\hline 3 & Iron $(\mathrm{Fe})$ Total & Required & Point & $\begin{array}{l}\text { Water Quality ID, Shape, } \\
\text { Point Name, Fe Total, X_Coordinates, Y_Coordinates, Mapping Date, Remarks }\end{array}$ \\
\hline 4 & Mn Total & Required & Point & $\begin{array}{l}\text { Water Quality ID, Shape, } \\
\text { Point Name, Fe Total, X_Coordinates, Y_Coordinates, Mapping Date, Remarks }\end{array}$ \\
\hline 5 & Water $\mathrm{pH}$ & Required & Point & $\begin{array}{l}\text { Water Quality ID, Shape, } \\
\text { Point Name, pH, X_Coordinates, Y_Coordinates, Mapping Date, Remarks }\end{array}$ \\
\hline 6 & Turbidity & Required & Point & $\begin{array}{l}\text { Water Quality ID, Shape, } \\
\text { Point Name, Turbidity, X_Coordinates, Y_Coordinates Mapping Date, Remarks }\end{array}$ \\
\hline 7 & Salinity & Required & Point & $\begin{array}{l}\text { Water Quality ID, Shape, } \\
\text { Point Name, Salinity, X_Coordinates, Y_Coordinates, Mapping Date, Remarks }\end{array}$ \\
\hline
\end{tabular}

Table 8. Description of the baseline soil quality datasets.

\begin{tabular}{|c|c|c|c|c|}
\hline No & LAYER & $\begin{array}{l}\text { Requirement } \\
\text { Level }\end{array}$ & $\begin{array}{l}\text { Geometry } \\
\text { Type }\end{array}$ & Required Attributes \\
\hline 1 & $\begin{array}{l}\text { Soil quality } \\
\text { point }\end{array}$ & Required & Point & $\begin{array}{l}\text { Soil Quality ID, Shape, } \\
\text { Soil type, X_Coordinates, Y_Coordinates sample depth, Mapping Date, Remarks }\end{array}$ \\
\hline 2 & $\begin{array}{l}\text { Dumping soil } \\
\text { area }\end{array}$ & Required & Polygon & $\begin{array}{l}\text { Soil Quality ID, Shape, } \\
\text { Soil type, Shape area, shape length, sample depth, Mapping Date, Remarks }\end{array}$ \\
\hline 3 & Soil pH & Required & Point & $\begin{array}{l}\text { Soil Quality ID, Shape, } \\
\text { Point Name, Soil type, pH, X_Coordinates, Y_Coordinates, Mapping Date, Remarks }\end{array}$ \\
\hline 4 & Heavy metals & Required & Point & $\begin{array}{l}\text { Soil Quality ID, Shape, } \\
\text { Point Name, Soil type, heavy metals, X_Coordinates, Y_Coordinates, Mapping Date, Remarks }\end{array}$ \\
\hline 5 & $\begin{array}{l}\text { Cation } \\
\text { exchange } \\
\text { capacity }\end{array}$ & Required & Point & $\begin{array}{l}\text { Soil Quality ID, Shape, } \\
\text { Point Name, Soil type, exchange capacity, X_Coordinates, Y_Coordinates, Mapping Date, Remarks }\end{array}$ \\
\hline 6 & Soil nutrient & Required & Point & $\begin{array}{l}\text { Soil Quality ID, Shape, } \\
\text { Point Name, Soil type, nutrients, X_Coordinates, Y_Coordinates Mapping Date, Remarks }\end{array}$ \\
\hline
\end{tabular}




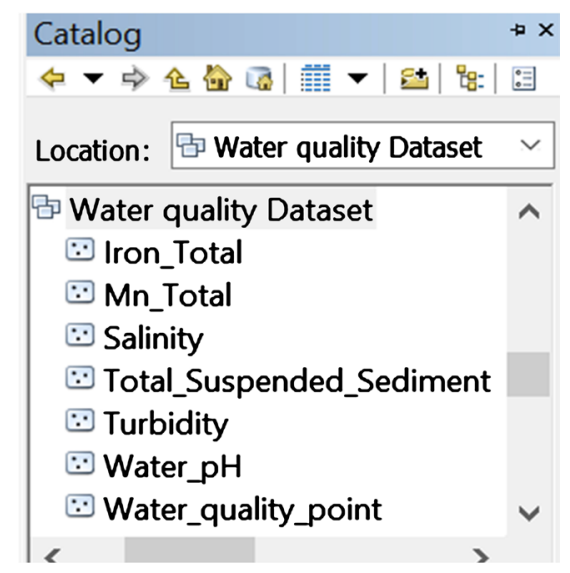

Figure 9. Feature classes of the baseline surface and ground water quality dataset.

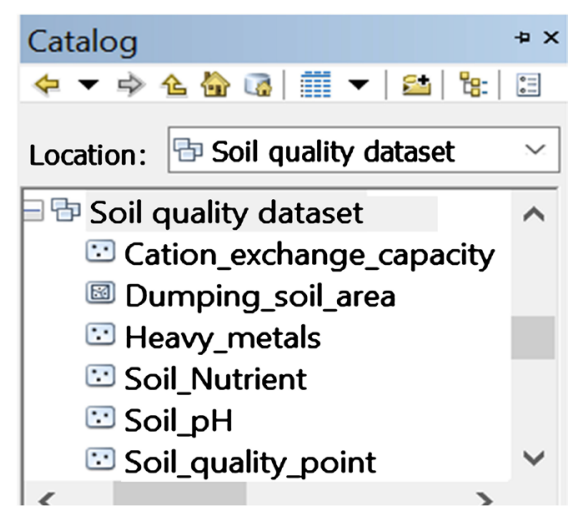

Figure 10. Feature classes of the baseline soil quality data.

\subsection{Creating the Baseline Socio-Economic Dataset}

The socio-economic environment is defined as all activities, and social and economic processes, that could be influenced directly or indirectly by the mining project which includes the size and distance of built environment, built-up, cultural values, historical monuments, the function of the examined area. This dataset contains nine feature class includes, socio-economic quality point, Quality of life, Housing quality and quantity (this is particularly important if people are to be relocated), Public safety (police, fire), Education (average level, access, public and/or private), Health services, Recreation (public, private), public services sanitation, livelihood. In this dataset, the field attributes related to field measurement results are not filled in using specific code but filled with real results of field measurements. Figure 11 illustrates the design of the geodatabase in the ArcGIS/ArcCatalog software. Attributes of these future classes are further illustrated in Table 9.

\subsection{Creating the Baseline Population Dataset}

The baseline population datasets mainly contain location of the local population about the proposed project area, this dataset contains four feature classes which 
includes population size, (age composition, growth) Economic activities, employment facility and income (inventory of present economic environment without the project) usually measured with surveys and interviews. Figure 12 illustrates the Composite baseline population dataset; Figure 12 illustrates the design of the geodatabase in the ArcGIS/ArcCatalog software. Attributes of these future classes are further illustrated in Table 10.

\subsection{Creating Baseline Waste Management Dataset}

The baseline waste management dataset contains six feature classes related to waste generated during the mining operation. This dataset includes waste point, solid waste, chemical waste, waste treatment plant (WTP), tailings impoundment facility, and tailings disposal. Figure 13 illustrates the Composite baseline waste management dataset; Figure 13 illustrates the design of the geodatabase in the ArcGIS/ArcCatalog software. Attributes of these future classes are further illustrated in Table 11. Each feature class contains information include point name, spatial position, and field check result.

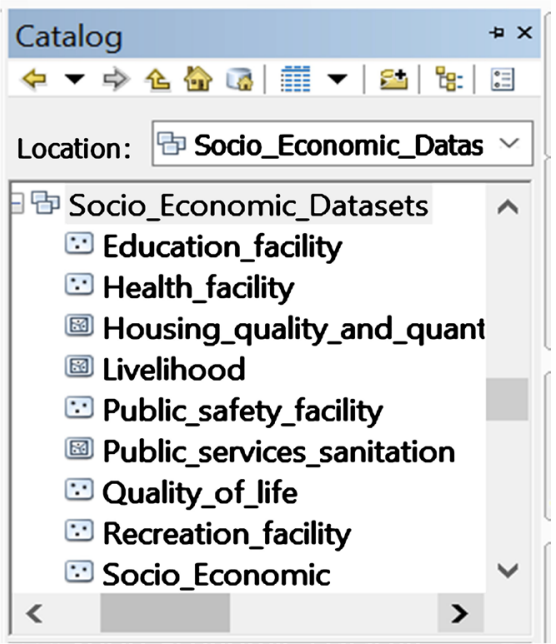

Figure 11. Feature classes of the baseline socio-economic dataset.

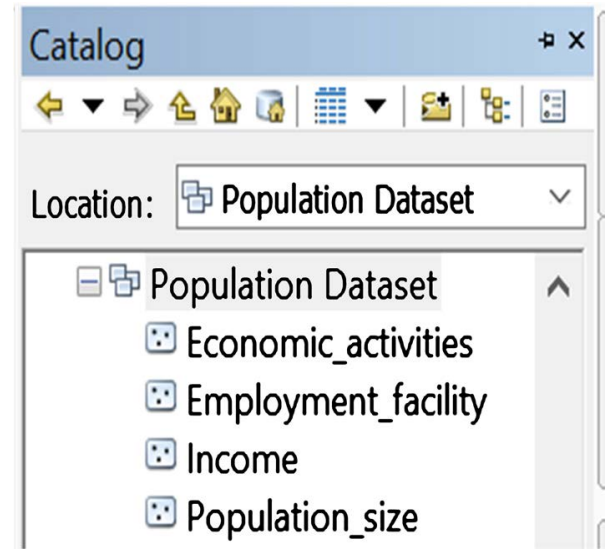

Figure 12. Feature classes of the baseline polulation dataset. 


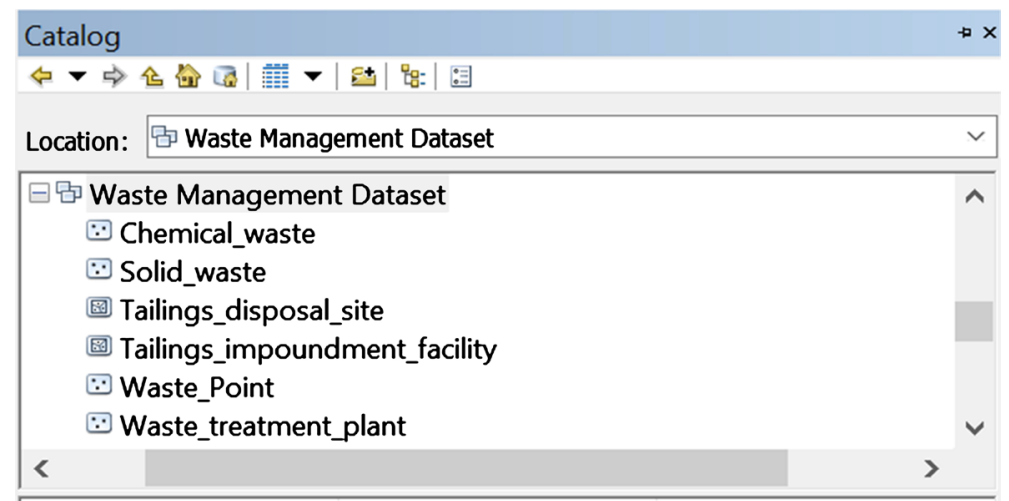

Figure 13. Feature classes of the baseline waste management dataset.

Table 9. Description of the baseline socio-economic dataset.

\begin{tabular}{|c|c|c|c|c|}
\hline No & LAYER & $\begin{array}{l}\text { Requirement } \\
\text { Level }\end{array}$ & $\begin{array}{l}\text { Geometry } \\
\text { Type }\end{array}$ & Required Attributes \\
\hline 1 & Socio-economic & Required & Point & $\begin{array}{l}\text { Socio-Economic ID, SE type, Village, town X_Coordinates, Y_Coordinates, Mapping Date, } \\
\text { Remarks }\end{array}$ \\
\hline 2 & Quality of life & Required & point & $\begin{array}{l}\text { Socio-Economic ID, Shape, } \\
\text { SE type, Village, Town, Quality of life, Mapping Date, Remarks }\end{array}$ \\
\hline 3 & $\begin{array}{l}\text { Housing quality } \\
\text { and quantity }\end{array}$ & Required & Point & $\begin{array}{l}\text { Socio-Economic ID, } \\
\text { SE type, Village, town, housing quality, X_Coordinates, Y_Coordinates, Mapping Date, Remarks }\end{array}$ \\
\hline 4 & $\begin{array}{l}\text { Public safety } \\
\text { facility }\end{array}$ & Required & Point & $\begin{array}{l}\text { Socio-Economic ID, } \\
\text { SE type, Village, town, facility type, X_Coordinates, Y_Coordinates, Mapping Date, Remarks }\end{array}$ \\
\hline 5 & Education facility & $y$ Required & Point & $\begin{array}{l}\text { Socio-Economic ID, } \\
\text { SE type, Village, town, facility type, } X_{-} \text {Coordinates, } Y_{-} \text {Coordinates, Mapping Date, Remarks }\end{array}$ \\
\hline 6 & Health facility & Required & Point & $\begin{array}{l}\text { Socio-Economic ID, } \\
\text { SE type, Village, town, facility. type, } \mathrm{X} \text { _Coordinates, } \mathrm{Y} \text { _Coordinates, Mapping Date, Remarks }\end{array}$ \\
\hline 7 & $\begin{array}{l}\text { Recreation } \\
\text { facility }\end{array}$ & Required & Point & $\begin{array}{l}\text { Socio-Economic ID, } \\
\text { SE type, Village, town, facility. type, X_Coordinates, Y_Coordinates, Mapping Date, Remarks }\end{array}$ \\
\hline 8 & $\begin{array}{l}\text { public services } \\
\text { sanitation }\end{array}$ & Required & Point & $\begin{array}{l}\text { Socio-Economic ID, } \\
\text { SE type, Village, town, facility. type, X_Coordinates, Y_Coordinates, Mapping Date, Remarks }\end{array}$ \\
\hline 9 & Livelihood & Required & Polygon & $\begin{array}{l}\text { Socio-Economic ID, shape, shape area, shape length } \\
\text { SE type, Village, town, livelihood type, Mapping Date, Remarks }\end{array}$ \\
\hline
\end{tabular}

Table 10. Description of the baseline population dataset.

\begin{tabular}{|c|c|c|c|c|}
\hline No & LAYER & Requirement Level & Geometry Type & Required Attributes \\
\hline 1 & Population size & Required & Point & $\begin{array}{l}\text { Population ID, age composition, size, growth, X_Coordinates, } \\
\text { Y_Coordinates Mapping Date, Remarks }\end{array}$ \\
\hline 2 & Economic activities & Required & Polygon & $\begin{array}{l}\text { Population ID, age composition, size, growth, activity, X_Coordinates, } \\
\text { Y_Coordinates Mapping Date, Remarks }\end{array}$ \\
\hline 3 & Employment facility & Required & Point & $\begin{array}{l}\text { Population ID, age composition, size, growth, facility, X_Coordinates, } \\
\text { Y_Coordinates Mapping Date, Remarks }\end{array}$ \\
\hline 4 & Income & Required & Point & $\begin{array}{l}\text { Population ID, age composition, size, growth, income type, } \\
\text { X_Coordinates, Y_Coordinates Mapping Date, Remarks }\end{array}$ \\
\hline
\end{tabular}


Table 11. Description of the baseline waste management dataset.

\begin{tabular}{|c|c|c|c|c|}
\hline No & LAYER & $\begin{array}{l}\text { Requirement } \\
\text { Level }\end{array}$ & $\begin{array}{l}\text { Geometry } \\
\text { Type }\end{array}$ & Required Attributes \\
\hline 1 & Waste point & Required & Point & $\begin{array}{l}\text { Waste ID, Shape, Point Name } \\
\text { X_Coordinates, Y_Coordinates Results, } \\
\text { Mapping Date, Remarks }\end{array}$ \\
\hline 2 & Solid waste & Required & Point & $\begin{array}{l}\text { Waste ID, Shape, Point Name } \\
\text { X_Coordinates, Y_Coordinates Results, } \\
\text { Mapping Date, Remarks }\end{array}$ \\
\hline 3 & Chemical waste & Required & Point & $\begin{array}{l}\text { Waste ID, Shape, Point Name } \\
\text { X_Coordinates, Y_Coordinates Results, } \\
\text { Mapping Date, Remarks }\end{array}$ \\
\hline 4 & $\begin{array}{l}\text { Waste treatment } \\
\text { plant (WTP) }\end{array}$ & Required & Point & $\begin{array}{l}\text { Waste ID, Shape, Point Name } \\
\text { X_Coordinates, Y_Coordinates Results, } \\
\text { Mapping Date, Remarks }\end{array}$ \\
\hline 5 & $\begin{array}{l}\text { Tailings } \\
\text { impoundment } \\
\text { facility (TIF) }\end{array}$ & Required & Polygon & $\begin{array}{l}\text { Waste ID, Shape, Shape Name, Shape length, } \\
\text { Shape Area, Results, Mapping Date, Remarks }\end{array}$ \\
\hline 6 & $\begin{array}{l}\text { Tailings disposal } \\
\text { site (TDS) }\end{array}$ & Required & Polygon & $\begin{array}{l}\text { Waste ID, Shape, Shape Name, Shape length, } \\
\text { Shape Area, Results, Mapping Date, Remarks }\end{array}$ \\
\hline
\end{tabular}

\subsection{Creating the Baseline Climate Change Dataset}

The baseline climate change dataset contains six feature classes related to climate conditions around the surroundings of the mine site operation and concession area. This dataset includes a Concession area, Rainfall, temperature, air, protected, and sensitive areas. Figure 14 illustrates the design of the geodatabase in the ArcGIS/ArcCatalog software. Attributes of these future classes are further illustrated in Table 12. Each feature class contains information include point name, spatial position, and field check result.

\subsection{Composition of the Baseline GIS Spatial Geodatabase Template}

The baseline environmental GIS spatial database template for a proposed mining project contained ten (10) datasets with seventy-one (71) feature classes as shown in Figure 15. Geographic information systems (GIS) are founded upon the capability to organize information into a series of layers that can be integrated using geographic location. As a fundamental level, each GIS dataset is organized as a series of thematic layers to represent and answer questions about a particular problem set such as environmental impact assessment of mining. The basis of this step enables us to arrange the datasets required to support the baseline database of the EIA of mining and organized these data into logical feature sets. As it was discussed these blocks represent data groups or feature datasets. This provides us with a framework for understanding the design process that was presented throughout the geodatabase design. The geographic representations are organized in a series of thematic layers. A thematic layer is a collection of common geographic elements, such as road network, a collection of parcel 
boundaries, land use types, soil types, and elevation surface, and satellite imagery for a certain date or well locations. This concept of a thematic layer is to describe the distribution of the baseline data phenomenon and how it should be portrayed across a geographic extent. Most of the themes should be represented by a single collection of homogeneous features while other themes are represented by multiple datasets. Gridded datasets should be used to represent continuous surfaces, such as elevation, georeferenced imagery, slope, and aspect.

These data collections should be organized as feature classes and raster-based data layers. Figure 15 shows the overall view of the structure of the baseline spatial geodatabase datasets of Environmental Impact Assessments of mining. There are 10 environmental datasets and 71 feature classes. Those featured classes were grouped into feature datasets. Parameters which have the same characteristic and belong to a specific theme were grouped and organized into one

Table 12. Description of the baseline climate change dataset.

\begin{tabular}{|c|c|c|c|c|}
\hline No & LAYER & $\begin{array}{l}\text { Requirement } \\
\text { Level }\end{array}$ & $\begin{array}{l}\text { Geometry } \\
\text { Type }\end{array}$ & Required Attributes \\
\hline 1 & $\begin{array}{l}\text { Concession } \\
\text { area }(\mathrm{CA})\end{array}$ & Required & Point & $\begin{array}{l}\text { CA ID, Shape, Shape Name, Shape length, Shape } \\
\text { Area, Results, Mapping Date } \\
\text { Remarks }\end{array}$ \\
\hline 2 & Rainfall & Required & Point & $\begin{array}{l}\text { CA ID, Shape, Point Name } \\
\text { X_Coordinates, Y_Coordinates Results, Mapping } \\
\text { Date, Remarks }\end{array}$ \\
\hline 3 & Temperature & Required & Point & $\begin{array}{l}\text { CA ID, Shape, Point Name } \\
\text { X_Coordinates, Y_Coordinates Results, Mapping } \\
\text { Date, Remarks }\end{array}$ \\
\hline 4 & Air & Required & Point & $\begin{array}{l}\text { Waste ID, Shape, Point Name } \\
\text { X_Coordinates, Y_Coordinates Results, Mapping } \\
\text { Date, Remarks }\end{array}$ \\
\hline 5 & $\begin{array}{l}\text { Protected } \\
\text { areas }\end{array}$ & Required & Polygon & $\begin{array}{l}\text { CA ID, Shape, Shape Name, Shape length, Shape } \\
\text { Area, Results, Mapping Date } \\
\text { Remarks }\end{array}$ \\
\hline 6 & Sensitive areas & s Required & Polygon & $\begin{array}{l}\text { CA ID, Shape, Shape Name, Shape length, Shape } \\
\text { Area, Results, Mapping Date } \\
\text { Remarks }\end{array}$ \\
\hline
\end{tabular}

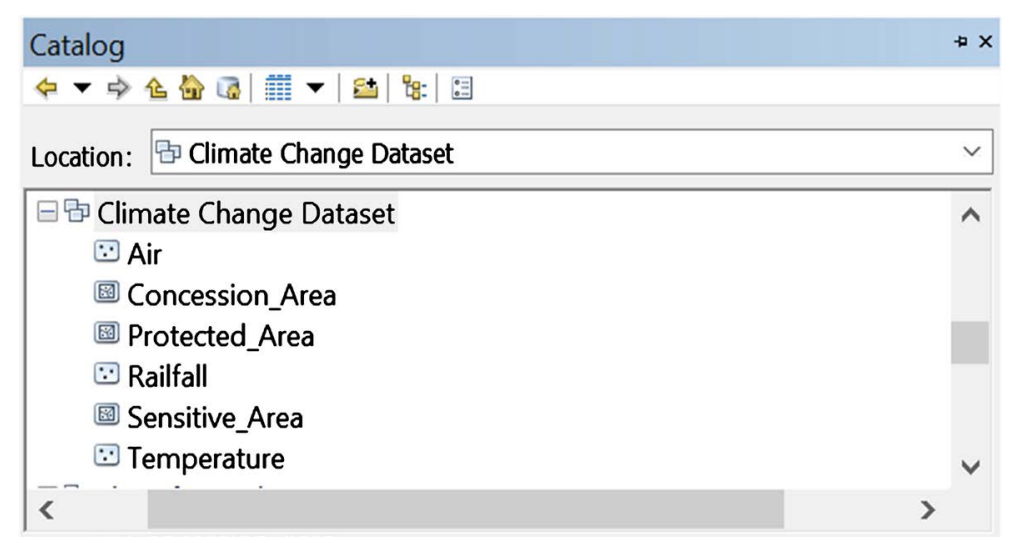

Figure 14. Feature classes of the baseline climate change datasets. 


\begin{tabular}{|c|l|}
\hline 它 & Air quality datasets \\
\hline$\square$ & Air Humidity \\
\hline$\because$ & Air Temperature \\
\hline$\square$ & Air Vibration \\
\hline$\square$ & Air quality point \\
\hline$\square$ & Ambient Air Quality \\
\hline$\square$ & Noise \\
\hline$\square$ & Rainfall \\
\hline$\square$ & Wind Speed \\
\hline
\end{tabular}

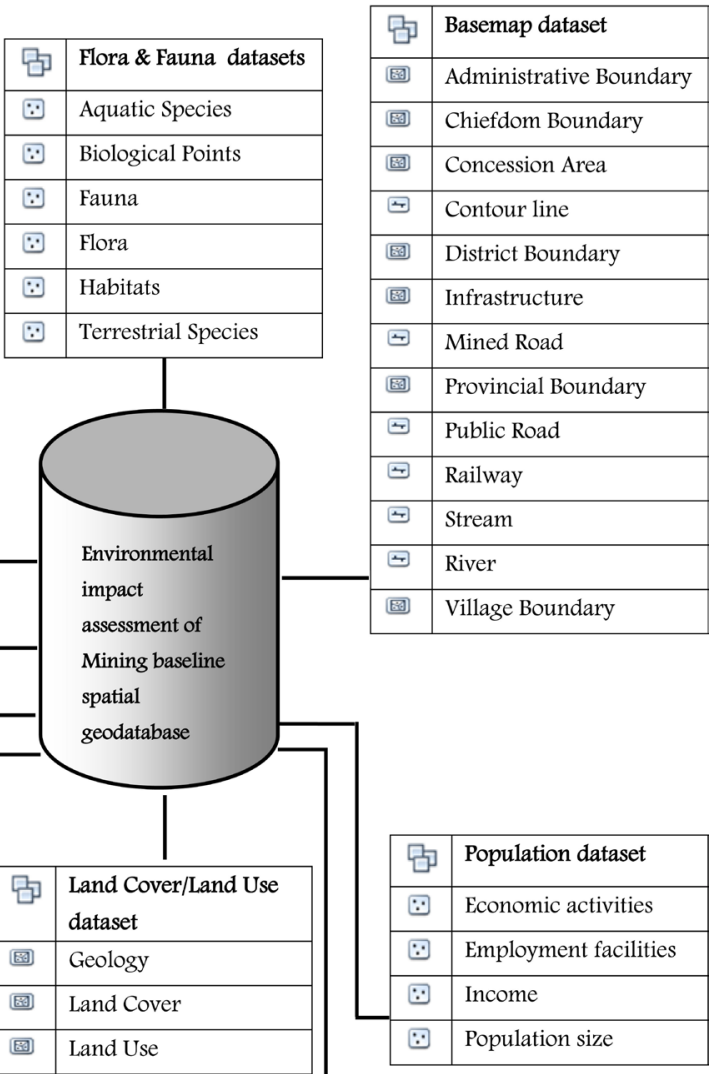

\begin{tabular}{|c|l|}
\hline 吕 & Soil dataset \\
\hline$\because$ & $\begin{array}{l}\text { Cation exchange } \\
\text { capacity }\end{array}$ \\
\hline$\square$ & Dumping soil area \\
\hline$\because$ & Heavy metals \\
\hline$\because$ & Soil nutrient \\
\hline$\because$ & Soil pH \\
\hline$\because$ & Soil quality point \\
\hline
\end{tabular}

\begin{tabular}{|c|c|}
\hline 它 & Water quality dataset \\
\hline$\because$ & Iron $(\mathrm{Fe})$ Total \\
\hline$\because$ & Mn Total \\
\hline$\because$ & Salinity \\
\hline$\because$ & $\begin{array}{l}\text { TSS (Total Suspended } \\
\text { Sediment) }\end{array}$ \\
\hline$\because$ & Turbidity \\
\hline$\because$ & Water $p H$ \\
\hline$\because$ & Water quality point \\
\hline 它 & Climate change dataset \\
\hline 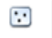 & Air \\
\hline 國 & Concession Area \\
\hline 圆 & Protected Area \\
\hline 圆 & Sensitive Area \\
\hline 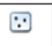 & Rainfall \\
\hline 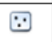 & Temperature \\
\hline
\end{tabular}

\begin{tabular}{|c|c|}
\hline ᄂ & dataset \\
\hline 國 & Geology \\
\hline 國 & Land Cover \\
\hline 回 & Land Use \\
\hline 圆 & Mined Out Land \\
\hline 國 & Soil \\
\hline 圆 & Topography \\
\hline 它 & $\begin{array}{l}\text { Waste management } \\
\text { dataset }\end{array}$ \\
\hline 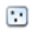 & Chemical waste \\
\hline$\because$ & Solid waste \\
\hline$\because$ & Waste point \\
\hline$\because$ & $\begin{array}{l}\text { Waste treatment plant } \\
\text { (WTP) }\end{array}$ \\
\hline$\because$ & $\begin{array}{l}\text { Tailings impoundment } \\
\text { facility (TIF) }\end{array}$ \\
\hline 圆 & Tailing disposal \\
\hline
\end{tabular}

\begin{tabular}{|l|l|}
\hline 它 & Socio Economic dataset \\
\hline$\square$ & Education facility \\
\hline$\square$ & Health facility \\
\hline$\square$ & $\begin{array}{l}\text { Housing quality \& } \\
\text { quantity }\end{array}$ \\
\hline$\square$ & Livelihood \\
\hline$\square$ & Public safety facility \\
\hline$\square$ & $\begin{array}{l}\text { Public service } \\
\text { sanitation }\end{array}$ \\
\hline$\square$ & Quality of life \\
\hline$\square$ & Recreation facility \\
\hline$\square$ & Socio-economic \\
\hline
\end{tabular}

Figure 15. Composition of the Baseline GIS spatial geodatabase template.

feature dataset. The grouping is not based on feature data type and attributes fields and it combines features that logically belong together. The datasets and data layers are grouped and subcategorized into blocks. As shown in Figure 15. The above blocks develop the conceptual data model, model features based on the data needed for the environmental impact assessment spatial analysis functions, and determine the spatial representation (i.e. point, polygon, line, image, surface) and non-spatial representation (i.e. attributes) of each feature. These blocks also create the logical data model, which will link the conceptual model with a GIS geodatabase. The list above is sorted by layer category, shows the vector data layers in the geodatabase that model real-world features as points, 
lines, or polygons in a UTM (WGS 1984) projected geographic coordinate system.

\section{Conclusion}

Baseline Environmental Impact Assessment (EIA) of mining projects in Sierra Leone creates a challenging environment for data collection and impact prediction. Geographic information systems (GIS)-based EIA, using appropriate spatial analysis methods can sufficiently reduce the challenges created by mining environments. However, application of GIS in mining EIA is always constrained by availability of an appropriate baseline digital geodatabase on environmental attributes, due to 1) the absence of comprehensive understanding of interrelated environment impacts caused by the mining of different minerals, 2) the environmental uniqueness of each mine, which makes it difficult to develop general tools of EIA analysis and models, 3) the availability of adequate spatial data, information and appropriate GIS techniques, 4) because of the dynamic characteristics and multivariate nature of the environment, it has often been difficult to collate, analyze and interpret its datasets, 5) lack of appropriate temporal and spatial resolution of remotely sensed imageries and accurate geospatial data can be a major limitation on spatial modeling, 6) finally, the availability of GIS professionals and affordability of GIS software and related hardware is a major constraint on EIA budgeting, especially for developing countries like Sierra Leone, on the other hand, with the rapid fall in price of PCs, internet service, open source GIS, online GIS, GPS integrated mobiles, and freely downloadable mobile apps there is an immense scope in geovisualization of spatio-temporal impacts of such EIA studies in mining areas. Therefore developing a Geographic Information Systems baseline geodatabase template for the evaluation of potential and predicted environmental impact for sustainable environmental impact assessment of mining in Sierra Leone will provide support to the data acquisition process of environmental impact assessment and offers a concept for developing analysis methods for environmental management of mining to minimize the undesired environmental impacts of mining and give an optimal proposal for data collection and analysis of mining industry in attaining sustainable development in Sierra Leone. Due to the limited available data, a conceptual GIS database template has been developed rather than a database case study of a mining site. No site investigation and data collection were undertaken. According to the trial done on the baseline GIS spatial geodatabase template, it has shown some encouraging results for evaluating potential and predicted environmental impacts assessment of mining projects in Sierra Leone. However, using the baseline spatial geodatabase template has many advantages; however, there are also several challenges to implement it. The geospatial database template was designed using ArcCatalog, ArcGIS 10.7.1. software. This offers a tempting avenue for further studies on designing environmental spatial analysis models for environmental impact assessment and ways of integrating into GIS. 


\section{Conflicts of Interest}

The author declares no conflicts of interest regarding the publication of this paper.

\section{References}

Bulla, M., Keresztes, P., \& Kóczy, T. L. (2004). A környezetben lejátszódó folyamatok elemzése Soft Computing módszerekkel. [Evaluation of Environmental Processes by/ using Soft Computing Methods.] In M. Bulla (Ed.), Komplex környezetállapot-értékelö szakértői rendszerek metodikai fejlesztése (pp. 119-129). Győr: Department of Environmental Engineering, Széchenyi István University. (In Hungarian)

EPA-SL Act (2010).

Kamara, S. M. (2019). Integration of GIS in the Development of an Environmental Cadastre Administrative System for the Environment. Protection Agency Sierra Leone. Journal of Geographic Information System, 11, 411-428. https://doi.org/10.4236/jgis.2019.114026.

Maryati, S., Shimada, H., Sasaoka, T., Hamanaka, A., Matsui, K., \& Nagawa, H. (2012). GIS Database Template for Environmental Management of Mining in Indonesia. Journal of Geographic Information System, 4, 62-70

http://dx.doi.org/10.4236/jgis.2012.41009 